\title{
PENDAPAT PARA ULAMA KABUPATEN GRESIK TERHADAP PENGGUNAAN UANG ELEKTRONIK MENURUT HUKUM ISLAM
}

\author{
Nabila Zulfatien Nisa' Al-Uluwiyah \\ UIN Sunan Ampel Surabaya \\ nabilazulfatien@gmail.com
}

\author{
Moh. Faizur Rohman \\ UIN Sunan Ampel Surabaya \\ faza_veiro@uinsby.ac.d
}

\begin{abstract}
This study aims to determine the opinion of the Ulama in Gresik Regency on the Use of Electronic Money according to Islamic Law. This field research uses a descriptive analysis method related to the views of the scholars of Gresik Regency on the use of electronic money. The data is then analysed using the Fatwa of the National Sharia Council (DSN) Number 116/DSN-MUI/IX/2017 concerning Sharia Electronic Money. Scholars in Gresik Regency stated that electronic money is only a modern payment tool in the card format that stores the money value in digital form. In general, electronic money can make it easier to use in all types of transactions, although it is not entirely reliable in terms of security. If the electronic money card is lost, the money value in the card will also be lost, and the owner cannot ask for accountability from any party. The scholars in Gresik Regency also stated that electronic money is halal and legal as long as it does not contain elements of gharar, is not used for things prohibited by religion. In purchasing electronic money, balances must be in the amount of cash paid so that usury does not occur. Thus this is also per the DSN-MUI Fatwa No. 116/DSN-MUI/IX/2017, which states that sharia electronic money is following sharia principles.
\end{abstract}

Keywords: Transaction, Electronic Money,

\begin{abstract}
Abstrak: Penelitian ini bertujuan mengetahui pendapat Para Ulama Di Kabupaten Gresik Terhadap Penggunaan Uang Elektronik Menurut Hukum Islam. Penelitian lapangan ini menggunakan metode deskriptif analisis terkait pendapat para ulama Kabupaten Gresik terhadap penggunaan uang elektronik. Data tersebut kemudian dianalisis dengan menggunakan Fatwa Dewan Syariah Nasional (DSN) Nomor 116/DSN-MUI/IX/2017 tentang Uang Elektronik Syariah. Para ulama di wilayah Kabupaten Gresik menyatakan bahwa uang elektronik hanyalah alat bantu pembayaran di era modern dalam bentuk kartu yang dapat menyimpan nilai uang
\end{abstract}

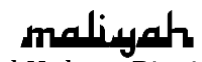

Jurnal Hukum Bisnis Islam

Volume 11, Nomor 01, Juni 2021

p-ISSN: 2088-4869/ e-ISSN: 2597-4351 
dalam bentuk digital. Secara umum uang elektronik dapat mempermudah penggunaan dalam segala jenis transaksi meskipun dari sisi keamanan tidak sepenuhnya dapat diandalkan. Hal itu karena apabila kartu uang elektroniknya hilang maka nilai uang yang di dalam kartu tersebut ikut hilang dan sebagai pemilik tidak dapat meminta pertanggung jawaban pada pihak manapun. Para ulama di Kabupaten Gresik juga menyatakan bahwa uang elektronik adalah halal dan boleh hukumnya selama hal itu tidak mengandung unsur gharar, tidak digunakan untuk hal-hal yang dilarang agama, dan dalam pembelian saldo uang elektronik harus sejumlah dengan uang tunai yang dibayarkan agar tidak terjadi riba. Maka hal ini juga sesuai dengan Fatwa DSN-MUI No 116/ DSN-MUI/IX/2017 yang menyatakan bahwa uang elektronik syariah adalah uang elektronik yang sesuai dengan prinsip syariah.

Kata Kunci: Transaksi, Uang Elektronik,

\section{Pendahuluan}

Pada sistem perekonomian dunia, fungsi utama uang adalah sebagai alat tukar (medium of exchange). Ini adalah fungsi utama uang. Dari fungsi utama ini, diturunkan fungsi-fungsi yang lain seperti uang sebagai standard of value (pembakuan nilai), store of value (penyimpanan kekayaan), unit of account (satuan penghitungan) dan standard of defferend payment (pembakuan pembayaran tangguh).1 Berdasarkan fungsi uang adalah alat tukar yang efesien dalam mengalokasikan sumber daya.

Seiring berjalannya waktu dan semakin canggihnya teknologi, perkembangan teknologi dan informasi telah memberi dampak ke berbagai bidang. Sehingga di era modern saat ini masyarakat telah dimudahkan segalanya dengan sistem elektronik. Seperti halnya dalam bertransaksi jual beli di kehidupan masyarakat juga dituntut untuk mengikuti zaman yang sudah semakin canggih dengan merubah pola pembayaran dari transaksi tunai menjadi transaksi non tunai. Sehubungan dengan kemajuan teknologi di era modern ini maka tercipta uang digital atau yang disebut dengan uang elektronik. Wujudnya tidak lagi berbentuk lembaran atau logam yang dapat dihitung jumlahnya, melaikan berupa data

\footnotetext{
${ }^{1}$ Nurul Huda, et,al, Lembaga Keuangan Islam (Jakarta: Kencana Prenada Media Grup, 2010), 12.
} 
Pendapat Para Ulama di Kabupaten Gresik Terhadap ...

digital yang dapat disimpan dalam sebuah kartu yang praktis sehingga dapat dibawa kemana- mana. Terhitung sejak 14 Agustus 2014, Bank Indonesia telah mencanangkan Gerakan Nasional Non Tunai (GNNT). Gerakan ini bertujuan mendorong masyarakat untuk mengurangi transaksi uang tunai. Mulai tanggal 31 Oktober 2017 telah diterapkan pembayaran menggunakan $e$-toll untuk jalan tol diseluruh Indonesia, yang menandakan bahwa Bank Indonesia terbukti semakin gencar dalam menggalakkan transaksi non tunai ini.

Uang elektronik memiliki nilai tersimpan atau prabayar dimana sejumlah nilai uang disimpan dalam suatu media elektronik yang dimiliki seseorang, dan nilai uang dalam uang elektronik akan berkurang pada saat konsumen menggunakannya untuk pembayaran. Hingga saat ini beberapa uang elektronik yang sudah beredar dan mendapat ijin dari Bank Indonesia diantaranya adalah bank BCA dengan Flazz, bank Mandiri dengan emoney, Bank BNI dengan Tapcash, Bank BRI dengan BRIZZI, dan masih banyak yang lainnya. Kartu uang elektronik perdana dapat dibeli dengan mudah tanpa mempersyaratkan seseorang memiliki rekening perbankan.

Apapun dan berapapun satuan nilai dalam media uang elektronik tersebut pada dasarnya berupa nilai uang yang pada waktunya akan ditukarkan dari pedagang kepada penerbit dalam bentuk uang tunai, maka pertukaran ini dapat dikatan sebagai transaksi jual beli khususnya jual beli mata uang (assharf). Secara terminologi fikih jual beli itu sendiri disebut dengan al-bay' yang berarti menjual, mengganti, dan menukar sesuatu dengan sesuatu yang lain. Menurut Abu Hanifah pengertian jual beli (al-bay') secara definitif yaitu tukarmenukar harta benda atau sesuatu yang diinginkan dengan sesuatu yang sepadan melalui cara tertentu yang bermanfaat. Adapun menurut Malikiyah, Syafi'iyah, dan Hanabilah, bahwa jual beli (al-bay') yaitu tukar-menukar harta dengan harta pula dalam bentuk pemindahan milik dan kepemilikan. ${ }^{2}$

\footnotetext{
${ }^{2}$ Mardani, Fiqh Ekonomi Syariah (Jakarta: Kencana Prenada Media Grup,2011), 101.
} 
Dasar hukum jual-beli telah diatur dalam Al-Qur'an dan Hadis, diantaranya adalah ${ }^{3}$ :

"Dan Allah telah menghalalkan jual beli dan mengharamkan riba”. (QS. al-Baqarah: 275)

"Hai orang-orang yang beriman, janganlah kamu memakan riba dengan berlipat ganda dan bertakwalah kamu kepada Allah Swt supaya kamu mendapat keberuntungan". (Qs. Ali Imron: 130)

Dalam penggunaan uang elektronik dapat dirujuk pada hadis riwayat Muslim, Abu Daud, Tirmizi, Nasa'i dan Ibn Majah, dengah teks Muslim dari Ubadah bin Shamit:

"Diriwayatkan oleh Abu Ubadah bin ash Shamid berkata, bahwa telah bersabda Rasulullah saw, "Emas (hendaklah dibayar) dengan emas, perak dengan perak, gandum dengan gandum, beras dengan beras, kurma dengan kurma, dan garam dengan garam, sama dan sejenis haruslah dari tangan ke tangan (sah). Maka, apabila berbeda jenisnya juallah sekehendak kalian dengan syarat kontan".(HR.Muslim) ${ }^{4}$

Hadis ini menekankan bahwa syarat pertukaran mata uang yang jenisnya sama adalah kualitas dan kuantitasnya sama serta dilakukan secara tunai dengan arti pembayaran harus dilakukan seketika itu juga dan tidak boleh diutang.

Akad jual beli merupakan transaksi yang dilakukan oleh pihak penjual dan pembeli atas suatu barang dan jasa yang menjadi objek jual beli. Dalam akad ini terdapat beberapa rukun, diantaranya: ${ }^{5}$

1. Penjual (Bāi')

2. Pembeli (Mushtari)

${ }^{3}$ Adiwarman Karim, Riba Gharar dan Kaidah-Kaidah Ekonomi Syariah Analisis Fikih \& Ekonomi (Jakarta: Raja Grafindo Persada, 2015), 10.

4 Sutan Remy Sjahdeini, Perbankan Islam dan Kedudukannya dalam Tata Hukum Perbakan Indonesia (Jakarta; Pustaka Utama Grafiti, 1999), 87.

${ }^{5}$ MBA Ismail, Perbankan Syariah (Jakarta : Prenadamedia Group, 2014), 136 
Pendapat Para Ulama di Kabupaten Gresik Terhadap ...

3. Objek jual beli $(M a b \bar{i})$

4. Harga (Thaman)

5. Ijab Kabul (Șighat)

Transaksi jual beli harus terpenuhi dalam empat syarat; yaitu syarat terjadinya transaksi, syarat sah jual beli, syarat berlaku jual beli, dan syarat keharusan (komitmen) jual beli. Tujuan dari syarat ini secara umum untuk menghindari terjadinya sengketa di antara manusia, melindungi kepentingan kedua belah pihak, menghindari terjadinya (kemungkinan) manipulasi dan menghilangkan kerugian karena faktor ketidaktahuan. Dengan begitu, jika sebuah transaksi tidak memenuhi syarat terjadinya transaksi, maka transaksi dianggap batal. ${ }^{6}$

Namun pada prakteknya uang elektronik ini dapat digunakan untuk keperluan non syariah. Oleh karena itu dari sekian banyak pengguna dan kemudahan bertransaksi menggunakan uang elektronik tersebut, masyarakat yang peduli akan keuangan syariah khawatir akan produk tersebut karena produk Uang Elektronik dikuasai oleh perbankan konvensional maupun institusi keuangan lain yang tidak berjalan sesuai prinsip syariah.

Berangkat dari latar belakang masalah inilah penulis ingin membahas lebih jauh tentang bagaimana pendapat para tokoh ulama terhadap penggunaan uang elektronik dalam transaksi, dimana hingaa saat ini masyarakat masih pro dan kontra terhadap kebijakan dari penggunaan uang elektronik itu sendiri.

Dalam penelitian ini, penulis menggunakan metode analisis deskriptif-analisis, yaitu metode penulisan yang berusaha menggambarkan bagaimana pendapat para ulama terhadap penggunaan uang elektronik pada setiap transaksi yang diperoleh sesuai dengan keadaan yang sebenarnya, kemudian dianalisis dengan Fatwa DSN Nomor 116/DSN-MUI/IX/2017 tentang Uang Elektronik Syariah. Penelitian ini dideskripsiskan

\footnotetext{
${ }^{6}$ Wahbah Az-Zuhaili, Fiqh Islam Wa Adillatuhu, terj Abdul Hyyie al-Kattani et, al, juz 5(Jakarta: Gema Insani, 2011), 34
} 
data menggunakan pola pikir induktif yaitu dari suatu permasalahan tentang pendapat para ulama terhadap penggunaan uang elektronik pada setiap transaksi yang bersifat khusus, kemudian dianalisa dan dijabarkan hukumnya berdasarkan Fatwa DSN Nomor 116/DSN-MUI/IX/2017 tentang Uang Elektronik Syariah untuk mengambil kesimpulan.

\section{Uang Elektronik}

Manfaat atau kelebihan dari penggunaan uang elektronik dibandingkan dengan uang tunai adalah (1) Lebih cepat dan nyaman dibandingkan dengan uang tunai, khususnya untuk transaksi yang bernilai kecil (micro payment), disebabkan nasabah tidak perlu menyediakan sejumlah uang pas untuk suatu transaksi atau harus menyimpan uang kembalian. Selain itu, kesalahan dalam menghitung uang kembalian dari suatu transaksi tidak terjadi apabila menggunakan uang elektronik. (2) Waktu yang diperlukan untuk menyelesaikan suatu transaksi dengan uang elektronik dapat dilakukan jauh lebih singkat dibandingkan transaksi dengan kartu kredit atau kartu debit, karena tidak harus memerlukan proses otorisasi on-line, tanda tangan maupun PIN. Selain itu, dengan transaksi off-line, maka biaya komunikasi dapat dikurangi. (3) Electronic value dapat diisi ulang kedalam kartu e-money melalui berbagai sarana yang disediakan oleh issuer. ${ }^{7}$

Sedangkan Secanggih apapun uang elektronik tentunya memiliki kekurangan yang perlu diwaspadai, diantaranya adalah: (1) Menuntut seseorang untuk mempelajari hal baru, apalagi bagi mereka yang belum melek teknologi. Tentu ini merupakan salah satu kendala saat penggunaan metode pembayaran dengan uang elektronik di masyarakat. (2) Masih kurangnya fasilitas-fasilitas penunjang penggunaan uang elektronik di sejumlah daerah, apalagi jika sedang berada di daerah-daerah pelosok yang minim akses khususnya internet.

7 Siti Hidayati et. all., Kajian Operasional E-money, (Jakarta: Bank Indonesia, 2006), 5 
Pendapat Para Ulama di Kabupaten Gresik Terhadap ...

Jadi penggunaan uang elektronik masih terbatas untuk kotakota besar saja. (3) Berisiko mengalami peretasan, dikarenakan berhubungan langsung dengan penggunaaan internet, namun untuk beberapa layanan uang elektronik tentu sudah memiliki proteksi yang dapat diandalkan. (4) Jika kartu atau aplikasi uang elektronik dimana anda menyimpan uang tersebut bisa saja hilang, dikarenakan kesalahan software dan lain sebagainya.

Adanya metode pembayaran menggunakan uang elektronik saat ini, harus diakui telah menjadi terobosan dan solusi yang dapat diandalkan untuk mempermudah transaksi keuangan dan pembayaran di masyarakat. Dimana ekonomi digital bisa menjadi solusi atas permasalahan ekonomi yang sering terjadi di dunia saat ini. Dampak dari hadirnya uang elektronik ini juga dapat dirasakan oleh para pihak yang menyelenggarakan, diantaranya:

1. Dampak bagi penerbit (Issuer)

Penerbit atau issuer adalah pihak yang membuat dan menyediakan kartu uang elektronik, penerbit uang elektronik terdiri dari sektor perbankan dan non perbankan. Para penerbit tersebut telah sah dan legal untuk membuat uang elektronik karena telah mengantongi izin dari Bank Indonesia. Penerbit yang telah disahkan oleh Bank Indonesia tersebut dapat menyediakan kartu uang elektronik bagi masyarakat. Dengan hadirnya uang elektronik maka bertambah pula jenis fasilitas pembayaran non tunai yang disediakan perbankan. Karena uang elektronik sendiri merupakan bagian dari alat pembayaran non tunai dengan menggunakan kartu.

Peningkatan konsumsi dan pertumbuhan ekonomi yang terjadi dari penggunaan uang elektronik tersebut pada gilirannya berpotensi mendorong kembali permintaan masyarakat terhadap uang non tunai guna mempermudah dan mempercepat proses transaksi yang dilakukan. Bagi bank atau lembaga penerbit pembayaran non tunai, hal ini 
kembali berpotensi pendapatan dan keuntungan. Hal ini disebut sebagai dampak berganda dari penggunaan alat pembayaran non tunai. Dampak berganda dari penggunaan pembayaran non tunai kepada konsumen dan pengusaha tersebut pada gilirannya dapat mendorong pertumbuhan ekonomi. ${ }^{8}$

2. Dampak bagi pedagang (Merchant)

Pengusaha atau merchant dalam sistem uang elektronik ini adalah pengusaha atau pedagang yang menyediakan penggunakan fasilitas jasa pembayaran dengan uang elektronik dalam transaksi pembayarannya. Pengusaha dalam hal ini berupaya menyiapkan hal ini untuk meningkatkan efektifitas dan efisiensi usahanya.

Dari sisi pengusaha, peningkatan konsumsi yang diikuti dengan efisiensi biaya transaksi akan meningkatkan profit bagi pengusaha yang kemudian berpotensi untuk mendorong aktivitas usaha dan eskpansi usaha. Semakin efisien biaya transaksi yang diperoleh dari penggunaan alat pembayaran non tunai semakin besar potensi peningkatan output. Hal ini pada gilirannya mendorong peningkatan produksi di sektor riil yang dapat mendorong pertumbuhan ekonomi. Sementara efisiensi yang terjadi dari penggunaan uang elektronik bagi pengusaha adalah keamanan dalam tiap transaksi, dimana pengusaha tidak perlu khawatir akan adanya uang palsu dan saat transaksi selesai maka uang dari pembayaran akan masuk rekening pengusaha yang terhubung dengan transaksi. ${ }^{9}$

3. Dampak bagi pengguna kartu uang elektronik (Costumer)

${ }^{8}$ R. Serfianto, dkk, Untung Dengan Kartu Kredit, Kartu ATM-Debit, \& Uang Elektronik, (Visi Media: Jakarta 2012), 98

${ }^{9}$ Arsita Ika Adiyanti, Pengaruh Pendapatan, Manfaat, Kemudahan Penggunaan, Daya Tarik Promosi, dan Kepercayaan terhadap Minat menggunakan layanan Emoney, 2015, Jurnal Ilmu Ekonomi Univeristas Brawijaya, 10 
Pendapat Para Ulama di Kabupaten Gresik Terhadap ...

Di era sekarang ini orang enggan membawa uang dalam jumlah yang besar di dalam sakunya karena selain dipandang tidak aman juga dinilai tidak praktis. Besar kecilnya uang yang dibawa oleh masyarakat dalam melakukan transaksi pembayaran dapat menjadi pertimbangan sebagai kendala keefisiensian dalam pembayaran. Kehadiran alat pembayaran non tunai seperti uang elektronik yang berbentuk kartu menghilangkan kendala tersebut dan berpotensi untuk mendorong kenaikan tingkat konsumsi. Kemudahan dalam berbelanja yang diberikan kepada nasabah bank yang memiliki alat pembayaran non tunai seperti ATM, kartu debet dan kartu kredit dapat mendorong kenaikan konsumsi dari nasabah tersebut. Hal ini dapat mendorong menigkatnya perputaran uang. ${ }^{10}$

Menurut Fatwa DSN No 116/ DSN-MUI/IX/2017 tentang Uang Elektronik Syariah, uang elektronik (electronic money) adalah alat pembayaran yang memenuhi unsur-unsur berikut:

1. Diterbitkan atas dasar jumlah nominal uang yang disetor terlebih dahulu kepada penerbit;

2. Jumlah nominal uang disimpan secara elektronik dalam suatu media yang teregistrasi;

3. Jumlah nominal uang elektronik yang dikelola oleh penerbit bukan merupakan simpanan sebagaimana dimaksud dalam undang-undang yang mengatur mengenai perbankan;

4. Digunakan sebagai alat pembayaran kepada pedagang yang bukan merupakan penerbit uang elektronik tersebut.

Dengan kata lain uang elektronik merupakan instrumen pembayaran tanpa uang fisik (cashless money) bagi transaksi

${ }^{10}$ M. Sofyan Abidin, Dampak Kebijakan E-money di Indonesia Sebagai Alat Sistem Pembayaran Baru, 2016, Jurnal Ilmu Akuntansi Universitas Negeri Surabaya, 18 
keuangan yang bernilai kecil. Fungsi uang elektronik tidak jauh berbeda dengan fungsi uang tunai. Oleh karena itu, perlu dianalisis karakteristik uang elektronik sebagai alat pembayaran non tunai dan status uang elektronik dalam produk perbankan.

Uang Elektronik adalah sistem pembayaran secara elektronik yang dipergunakan untuk transaksi online, yakni elemen digital yang dibuat dan dapat digunakan sebagai uang. Penggunaan uang elektronik dalam bidang pembayaran mikro dianggap paling cocok. Kemunculan uang elektronik merupakan jawaban atas kebutuhan terhadap instrumen pembayaran mikro yang diharapkan mampu melakukan proses pembayaran secara cepat dengan biaya yang relatif murah, karena pada umumnya nilai uang yang disimpan instrumen ini ditempatkan pada suatu tempat tertentu yang mampu diakses secara cepat secara off-line, aman dan murah. ${ }^{11}$

Berdasarkan Peraturan Bank Indonesia Nomor 20/6/PBI/2018 tentang Perubahan Atas Peraturan Bank Indonesia Nomor 16/8/PBI/2014 tentang Uang Elektronik (Electronik Money) maka dapat dilihat pihak-pihak yang termasuk sebagai penyelenggara kegiatan alat pembayaran uang elektronik yaitu:

1. Penerbit adalah bank atau lembaga selain bank yang menerbitkan uang elektronik.

2. Pemegang uang elektronik adalah pihak yang menggunakan uang elektronik.

3. Prinsipal adalah bank atau lembaga selain bank yang bertanggung jawab atas pengelolaan sistem dan/atau jaringan antar anggotanya yang berperan sebagai penerbit dan/atau acquirer, dalam transaksi uang elektronik yang kerja sama dengan anggotanya didasarkan atas suatu perjanjian tertulis.

4. Acquirer adalah bank atau lembaga selain bank yang:

${ }^{11}$ Nufransa Wira Sakti, Buku Pintar E-commerce, (Jakarta: Transmedia Pustaka, 2014), 33 
Pendapat Para Ulama di Kabupaten Gresik Terhadap ...

a. Melakukan kerja sama dengan pedagang sehingga pedagang mampu memproses transaksi dari uang elektronik yang diterbitkan oleh pihak selain acquirer yang bersangkutan; dan

b. Bertanggung jawab atas penyelesaian pembayaran kepada pedagang.

5. Pedagang (merchant) adalah penjual barang dan atau jasa yang menerima transaksi pembayaran dari Pemegang.

6. Penyelenggara kliring adalah bank atau lembaga selain bank yang melakukan perhitungan hak dan kewajiban keuangan masing masing Penerbit dan/atau Acquirer dalam rangka transaksi uang elektronik.

7. Penyelenggara penyelesaian akhir adalah bank atau lembaga selain bank yang melakukan dan bertanggunglawab terhadap penyelesaian akhir atas hak dan kewajiban keuangan masing-masing penerbit dan/atau acquirer dalam rangka transaksi uang elektronik berdasarkan hasil perhitungan dari penyelenggara kliring.

8. Agen Layanan Keuangan Digital (LKD) adalah pihak ketiga yang bekerjasama dengan penerbit dan bertindak untuk dan atas nama penerbit dalam memberikan layanan keuangan digital. ${ }^{12}$

Selanjutnya, telah disebutkan dalam Fatwa DSN No.116/DSN-MUI/IX/2017 Tentang Uang Elektronik Syariah, uang elektronik boleh digunakan sebagai alat pembayaran dengan mengikuti ketentuan yang dimaksud dalam fatwa tersebut yaitu:

1. Akad antara penerbit dengan pemegang uang elektronik adalah akad wadiah atau akad qardh.

2. Diantara akad yang dapat digunakan penerbit dengan para pihak dalam penyelenggaraan uang elektronik seperti Prinsipal, acquirer, Pedagang (merchant), penyelenggara

\footnotetext{
${ }^{12}$ Perat uran Bank Indonesia Nomor 20/06/2018/PBI tentang Uang Elektronik
} 
kliring, dan penyelenggara penyelesaian akhir adalah akad ijarah, akad ju'alah, dan akad wakalah bi al-ujrah.

3. Diantara akad yang dapat digunakan antara penerbit dengan agen layanan keuangan digital adalah akad ijarah, akad jualah, dan akad wakalah bi al-ujrah. ${ }^{13}$

Transaksi pembayaran dengan uang elektronik pada prinsipnya dilakukan melalui pertukaran data elektronik antar dua media komputer dari pihak yang bertransaksi yaitu antara kartu konsumen dan terminal merchant. Jenis jenis transaksi dengan uang elektronik, secara umum meliputi:

1. Penerbitan (issuance) dan pengisian nilai uang (top-up)

Pengisian nilai uang pertama kali ke dalam kartu uang elektronik dapat dilakukan terlebih dahulu oleh issuer sebelum dijual kepada ke konsumen untuk selanjutnya konsumen dapat melakukan pengisian ulang (top up) yang umumnya dapat dilakukan melalui ATM dan terminalterminal pengisian ulang yang telah dilengkapi peralatan khusus oleh issuer. Proses pengisian ulang melalui ATM/terminal pada umumnya dirancang agar dapat langsung mempengaruhi/mendebet rekening nasabah yang telah terhubung secara otomatis dengan kartu uang elektronik milik konsumen.

2. Transaksi pembayaran

Pada saat seseorang melakukan pembayaran dengan menggunakan kartu uang elektronik, maka mekanisme yang dilakukan secara garis besar adalah sebagai berikut:

a. Konsumen meng-insert/mengarahkan kartu ke terminal merchant;

b. Terminal merchant memeriksa kecukupan saldo dalam kartu uang elektronik terhadap nominal yang harus dibayar;

\footnotetext{
${ }^{13}$ Fatwa Dewan Sariah Nasional Majelis Ulama Indonesia No: 116/DSNMUI/IX/2017 Tentang Uang Elektronik Syariah.
} 
Pendapat Para Ulama di Kabupaten Gresik Terhadap ...

c. Jika saldo pada kartu uang elektronik lebih besar dari nominal transaksi, terminal memerintahkan kartu untuk mengurangi saldo pada kartu sejumlah nominal transaksi.

d. Kartu milik konsumen kemudian memerintahkan terminal untuk menambah saldo pada terminal sebesar nominal transaksi. ${ }^{14}$

\section{Pendapat Para Ulama Di Kabupaten Gresik tentang Uang Elektronik}

Tiap hukum harus memiliki sifat pokok dan alat-alat yang memungkinkan untuk berkembang dan dapat mengikuti perubahan masa dan tempat, artinya hukum itu harus bersifat dinamis dan elastis, jika hukum tersebut ingin tetap hidup dan kekal. Begitu pula dengan hukum Islam terhadap penggunaan uang elektronik. Ulama di era modern seperti ini perlu mengkaji ulang setiap ada hal baru yang sekiranya menyebabkan pro dan kontra di masyarakat.

1. Menurut Ulama Lembaga Nahdlatul Ulama (NU) di Kabupaten Gresik

Ulama Nahdlatul Ulama menyatakan bahwa pengertian dari uang elektronik bukanlah dipersamakan sebagai uang, melainkan sebagai pengganti uang itu sendiri tetapi alat yang memudahkan transaksi disaat melakukan jasa yang dimaksud. Akad yang digunakan dalam uang elektronik adalah akad wadiah. Akad wadiah itu sendiri artinya adalah titipan. Suatu mekanisme dimana kita sebagai nasabah menitipkan uang di salah satu bank yang mengeluarkan kartu uang elektronik. Uang yang tersimpan itu dapat sewaktu- waktu kita ambil atau gunakan untuk membayar gerbang tol. Dalam Al-Qur'an sudah disebutkan ayat yang menerangkan tentang wadiah:

\footnotetext{
${ }^{14}$ Siti Hidayati et. all., Kajian Operasional E-money, (Bank Indonesia, 2006), 10
} 
"Sesungguhnya Allah menyuruh kamu menyampaikan amanat kepada yang berhak menerimanya". (QS. An-nisa :58)

Ulama Nahdlatul Ulama juga menyatakan bahwa hukum uang elektronik dinyatakan boleh, sebab kembali merujuk pada kaidah dasar muamalah, bahwa segala transaksi hukumnya boleh, asal tidak ada dalil yang melarangnya. Dijelaskan lebih lanjut oleh narasumber bahwa transaksi menggunakan uang elektronik ini sah-sah saja karena kita dapat mengetahui saldo nominalnya. ${ }^{15}$ Keberadaan uang elektronik perlu dikaji kembali, terkait apakah uang elektronik tersebut dapat dinyatakan sah sebagai pengganti uang ataupun hanya kartu elektronik yang berisi sejumlah nominal uang, sebab menurut Ulama Nahdlatul Ulama, sesungguhnya definisi uang itu sendiri adalah sebagai penyimpan nilai, ada satuan, dan memiliki nilai tukar. Namun pada kenyataannya, definisi uang elektronik berbeda dengan definisi uang pada umumnya. Uang elektronik tidak memiliki nilai tukar. Hanya sebagai alat ganti pembayaran, yang jika digunakan untuk pembayaran suatu transaksi hanya mengurangi nilai yang terkandung dalam sebuah kartu, bukan nilai dari uang itu sendiri, sebab yang terkandung dalam kartu elektronik sejumlah deposit. Selanjutnya masih menurut Ulama Nahdlatul Ulama, kelebihan dari uang elektronik diantaranya adalah memudahkan transaksi dan mengefesienkan waktu, serta meningkatkan tingkat kesadaran akan kemajuan teknologi di kalangan masyarakat. Sebaliknya, menurut beliau uang elektronik juga memiliki kekurangan. Salah satu diantaranya yang sangat berpengaruh adalah pengurangan

${ }^{15}$ Syifaul Qulub, Wawancara, 25 Juni 2018 
Pendapat Para Ulama di Kabupaten Gresik Terhadap ...

tenaga kerja di gerbang Tol. Satu gerbang Tol yang bisa memakan pekerja sebanyak 10-15 orang kini hanya membutuhkan paling banyak 5 orang. Tentu saja ini akan berpengaruh pada tingkat pengangguran yang bertambah di setiap daerah, khususnya daerah Kabupaten Gresik. Beliau menambahkan dalam mengatasi pengurangan tenaga kerja di Gerbang Tol alangkah baiknya pemerintah memberikan sosialisasi tentang berwirausaha, agar para pekerja yang kehilangan pekerjaannya akibat dampak dari penggunaan mesin uang elektronik di Gerbang Tol ini dapat membangun lapangan pekerjaannya sendiri.

2. Menurut Ulama Muhammadiyah di Kabupaten Gresik Menurut ulama muhammadiyah uang elektronik adalah sebuah alat bantu pembayaran di era modern dalam bentuk kartu yang dapat menyimpan nilai uang dalam bentuk digital. Dalam kerja fungsinya berbeda dengan uang tunai yang memang sebagai uang resmi negara kita, sebab sebagian masyarakat masih melakukan isi ulang kartu elektronik dengan menggunakan uang tunai.

Selaku narasumber, beliau mengatakan bahwa sesungguhnya masalah ekonomi adalah masalah muamalah bukan ubudiyah. Karena masalah ekonomi bersangkut paut dengan antar manusia yang satu dengan yang lain. Setiap kegiatan dalam ruang lingkup muamalah telah diatur dalam Al-Qur'an dan Hadis, sehingga manusia tidak bisa semena-mena dalam melakukan transaksi meskipun ini hanya menyangkut masalah perseorangan. Menurut beliau dasar hukum tentang uang elektronik merujuk pada kaidah dasar muamalah yang artinya "Pada dasarnya semua bentuk muamalah hukumnya boleh dilakukan, kecuali ada dalil yang mengharamkannya". Beliau menafsirkan ayat diatas bahwasanya dengan cara atau jalan apapun segala bentuk muamalah yang dilakukan sepanjang tidak 
digunakan untuk hal yang dilarang agama serta tidak mengandung unsur- unsur gharar maka hukumnya boleh. ${ }^{16}$ Pada saat menggunakan uang elektronik dalam bertransaksi mesti dilakukannya dengan asas suka sama suka, sebab menjadi salah satu dari syarat jual beli. Akan tetapi masih sering ditemukan sebagian masyarakat yang merasa terpaksa dengan adanya kebijakan terkait penggunaan uang elektronik, maka akan dikembalikan kembali kepada pengguna. Sebab apabila setiap orang memiliki hak kebebasan dalam memilih, baik memilih jasa uang secara tunai tau uang secara elektronik. Karena fungsi utama uang elektronik ini adalah alat yang mempermudah transaksi masyarakat untuk memenuhi kebutuhan seharihari di era modern ini, sebab sudah banyak perusahaan yang menyediakan layanan transaksi pembayaran uang elektronik.

Selanjutnya beliau menyatakan bahwa hal pasti memiliki dampak positif maupun negatif. Begitu pula dengan hadirnya uang elektronik di masa kini menjadikan setiap transaksi jadi lebih mudah, akan tetapi hal itu pula yang menyebabkan masyarakat di jaman sekarang semakin malas karena semakin dipermudah dengan kecanggihan teknologi. Interaksi antara penjual dan pembeli semakin berkurang disebabkan transaksi yang menggunakan mesin, sehingga hal ini menyebabkan manusia cenderung bersifat individual sehingga tidak memerlukan interaksi percakapan tawar menawar saat bertransaksi tidak perlu melakukan interaksi dan percakapan saat transaksi, namun dampak positif dari uang elektronik dapat mempermudah dan mempercepat kegiatan-kegiatan transaksi khususnya

16 Taufiqullah, Wawancara, 18 Juli 2018 
Pendapat Para Ulama di Kabupaten Gresik Terhadap ...

kini pada transaksi di jalan tol, tidak menutup kemungkinan akan dirasakan pada seluruh bentuk transaksi yang lain.

3. Menurut Ulama Lembaga Dewan Masjid Indonesia Kabupaten Gresik

Beliau mengartikan uang elektronik sebagai media pengganti uang tunai. Dimana uang tunai yang selama ini kadang menyulitkan dalam membawanya kini dipermudah dengan hadirnya uang elektronik. Hal ini dianggapnya sebagai satu bentuk pembaruan dari kartu ATM dan kartu debit yang biasanya hanya digunakan oleh orang- orang tertentu sedangkan uang elektronik dapat digunakan oleh berbagai kalangan. Sebab dalam proses memperolehnya tanpa harus menjadi nasabah terlebih dahulu. Hal ini memudahkan masyarakat desa sebab pada umumnya hanya sebagian kecil yang menjadi nasabah bank, terlebih lagi harga membeli kartu uang elektronik cukup terjangkau, dan dapat dibeli di berbagai swalayan atau minimart yang kini sedang marak. ${ }^{17}$

Dasar hukum yang digunakan untuk kasus uang elektronik adalah hadis yang artinya adalah "Emas (hendaklah dibayar) dengan emas, perak dengan perak, gandum dengan gandum, beras dengan beras, kurma dengan kurma, dan garam dengan garam, sama dan sejenis haruslah dari tangan ke tangan (sah). Maka, apabila berbeda jenisnya juallah sekehendak kalian dengan syarat kontan".

Hadis tersebut menjelaskan bahwa sebagaimana sebelum terciptanya uang sebagai alat tukar, transaksi menggunakan sistem barter, dimana penjual dan pembeli saling menukar barang sesuai kualitas dan kuantitasnya

${ }^{17}$ Hasil wawancara dengan bapak Zaeni pada tanggal 27 Juni 2018 
untuk menghindari adanya ketidakadilan dalam transaksi itu jual beli. Begitupun dalam transaksi uang elektronik, pembelian saldo uang elektronik yang terdapat dalam kartu uang elektronik harus sejumlah dengan uang tunai yang dibayarkan. Sebab apabila tidak sama jumlahnya maka dapat mengandung unsur riba. Lain halnya dengan biaya yang dikenakan untuk penambahan saldo atau biasa disebut topup. Biaya yang dikeluarkan dapat dianggap sebagai ujrah atau upah.

Kelebihan dari hadirnya uang elektronik selain mempersingkat waktu transaksi yakni mengurangi pembulatan nilai uang yang kadang merugikan salah satu pihak. Jika dalam satu pembelian tertera jumlah yang harus dibayar Rp 750,- namun pada praktiknya jaman sekarang susah sekali menemukan uang Rp 50,- sehingga harus dibulatkan menjadi Rp 800,- tentu saja hal ini dapat merugikan salah satu pihak. Kehadiran uang elektronik juga menjadi pemicu berkurangnya biaya percetakan uang tunai yang kini digantikan dengan uang bentuk digital dalam uang elektronik.

Namun sebaliknya, uang elektronik juga memiliki kekurangan, yakni pemerataan sosialisasi terkait uang elektronik belum sepenuhnya merata. Terdapat bukti yang masih sering ditemukan di berbagai Gerbang Tol tidak jarang ditemukan pengguna jalan tol yang masih belum memiliki kartu uang elektronik atau saldo kartu uang elektronik yang tidak mencukupi. Hal ini menyebabkan kerugian bagi pengguna jalan tol yang lainnya karena pengguna yang tidak memiliki kartu uang elektronik ini harus terlebih dahulu turun dan meminta tolong pada pengguna jalan tol yang dibelakang untuk meminjam kartu uang elektroniknya, sehingga penggunaan uang elektronik yang seharusnya mempercepat transaksi malah 
Pendapat Para Ulama di Kabupaten Gresik Terhadap ...

memperlambat pengguna lain yang memiliki kartu uang elektronik. Sehingga akibat yang belum meratanya sosialisasi ini menjadi lambat.

4. Menurut Ulama dari Yayasan Pondok Pesantren Qomaruddin (Bungah, Gresik)

Menurut beliau uang elektronik hanyalah sebuah kartu yang berisikan nilai uang sejumlah yang kita kehendaki. Statusnya dalam setiap transaksi hanya alat bantu pembayaran di tempat- tempat tertentu yang memang menyediakan fasilitas pembayaran menggunakan kartu uang elektronik. Dasar hukum uang elektronik memang tidak tertulis di kitab manapun, namun Rasulullah SAW pernah bersabda yang artinya "Kalian lebih mengetahui urusan dunia kalian".

Merujuk pada Hadis itu mengisyaratkan bahwa di masa mendatang, segala hal yang bersifat duniawi terutama dalam lingkup bermuamalah akan banyak perubahan dan berkembang. Sedangkan sudah tidak ada lagi ayat-ayat AlQur'an yang turun sebagai penjawab persoalan manusia di masa selanjutnya. Namun sebagai agama yang dinamis, hukum- hukum yang sudah ada dapat dipersamakan dan digunakan untuk menjawab berbagai persoalan manusia di masa kini dan masa mendatang. Begitu pula halnya dengan uang elektronik, dimana di masa Rasulullah jelas tidak ada, sehingga sebagai umat muslim tentu perlu dikaji terlebih dahulu halal dan haramnya. Namun kembali lagi mengingat tentang kaidah dasar bermuamalah, maka selagi uang elektronik belum ditemukan hal- hal yang membuatnya haram maka hukumnya boleh. ${ }^{18}$

Dalam mekanismenya, nilai uang yang tersimpan di kartu uang elektronik apabila kartunya hilang maka nilai uang

${ }^{18}$ Masykuri, Wawancara, 24 Juni 2018 
yang didalam kartu tersebut ikut hilang. Itu salah satu penyebab kurangnya minat beliau dalam menggunakan uang elektronik. Di masa mendatang apabila semua transaksi pembayaran menggunakan uang elektronik, secara otomatis setiap orang hanya akan membawa kartu uang elektronik itu tanpa membawa uang tunai. Lantas bagaimana dengan kewajiban kita yang sewaktu- waktu ingin bersedekah.

Apabila yang ada di kantong kita hanya ada uang dalam bentuk kartu. Meskipun memiliki banyak kekurangannya, uang elektronik juga memiliki kelebihan, misalnya mengurangi peredaran uang palsu. Kita selama ini sering mendengar berita tentang peredaran uang palsu yang jelas merugikan masyarakat luas dan juga negara. Oleh sebab itu kehadiran uang elektronik ini dianggap baik dari segi ini karena uang kertas yang banyak dipalsukan kini berganti menjadi uang dalam kartu.

5. Menurut Ulama dari Pondok Pesantren Nurul Qur'an Al Istiqomah (Sukorejo, Gresik)

Menurut beliau uang elektronik adalah alat bayar elektronik yang diperoleh dengan cara menyetorkan dahulu sejumlah uang ke bank penerbit uang elektronik, atau melalui agen-agen penerbit, atau dengan pengurangan sejumlah uang rekening di bank melalui mesin ATM. Nilai uang itu dimasukan menjadi nilai uang dalam media uang elektronik, yang dinyatakan dalam satuan Rupiah, dan digunakan untuk melakukan transaksi pembayaran dengan cara mengurangi secara langsung nilai uang pada media uang elektronik tersebut.

Bagaimanapun jenis transaksi itu selagi tidak merugikan salah satu pihak dan tidak mengandung unsur riba maka beliau menyatakan hukumnya boleh. Seperti dalam AlQur'an surat Ali Imron ayat 130: 
Pendapat Para Ulama di Kabupaten Gresik Terhadap ...

"Hai orang-orang yang beriman, janganlah kamu memakan riba dengan berlipat ganda dan bertakwalah kamu kepada Allah Swt supaya kamu mendapat keberuntungan". (Qs. Ali Imron: 130)

Diketahui bersama bahwa transaksi menggunakan uang eletronik sangatlah transparan. Kita dapat mengetahui dengan jelas perputaran uang kita dalam kartu tersebut. Kita juga dapat mengetahui nilai uang yang terkadung dalam kartu elektroniknya dengan cara mengecek saldo. ${ }^{19}$ Mengenai status uang elektronik dalam transaksi ini adalah sebagai alat pembayaran bukan sebagai mata uang karena sesungguhnya mata uang kita tetaplah rupiah yang berbentuk uang kertas dan uang logam. Dalam pembelian saldo uang elektronik pun kita menggunakan uang tunai yang berbentuk kertas dan logam. Maka sudah jelas bahwa uang elektronik hanyalah alat bantu pembayaran manusia di jaman modern.

Kelebihan dalam menggunakan uang elektronik pada setiap transaksi yang paling jelas adalah efisiensi waktu. Menggunakan uang tunai dengan uang elektronik memiliki selisih waktu beberapa menit. Sedangan bagi seorang pekerja, waktu 1 menit itu sangatlah berharga. Maka hadirnya uang elektronik ini sangat membantu dalam kecepatan waktu para penggunanya. Namun kekurangannya adalah masyarakat akan cenderung lebih boros, sebab kebiasaan memegang uang tunai mulai terganti dengan menggunakan uang elektronik yang mengakibatkan tidak terkontrolnya pengeluaran.

\section{Analisis Fatwa Dewan Syariah Nasional Nomor 116/DSN- MUI/IX/2017 Tentang Uang Elektronik Syariah Terhadap}

${ }^{19}$ Munir, Wawancara, 26 Juni 2018 


\section{Pendapat Para Ulama di Kabupaten Gresik dan Dasar Hukumnya Terhadap Penggunaan Uang Elektronik dalam Transaksi}

Menurut Fatwa DSN-MUI No 116/ DSN-MUI/IX/2017 tentang Uang Elektronik Syariah adalah alat pembayaran yang diterbitkan atas dasar jumlah nominal uang yang disetor terlebih dahulu kepada penerbit dengan jumlah nominal uang disimpan secara elektronik dalam suatu media yang teregistrasi dan dikelola oleh penerbit yang bukan merupakan simpanan sebagaimana dimaksud dalam undang-undang yang mengatur mengenai perbankan. Uang elektronik syariah adalah uang elektronik yang sesuai dengan prinsip- prinsip syariah. ${ }^{20}$

Menurut pendapat Ulama dari Nahdlatul Ulama, akad yang digunakan dalam uang elektronik diantaranya adalah akad wadiah. Akad wadiah itu sendiri artinya adalah titipan. Suatu mekanisme dimana kita sebagai nasabah menitipkan uang di salah satu bank yang mengeluarkan kartu uang elektronik. Uang yang tersimpan itu dapat sewaktu- waktu kita ambil atau gunakan untuk membayar gerbang tol. Dalam Al-Qur'an sudah disebutkan ayat yang menerangkan tentang wadiah "Sesungguhnya Allah menyuruh kamu menyampaikan amanat kepada yang berhak menerimanya" (QS. An-nisa :58)

Begitu pula dalam transaksi uang elektronik, menurut ulama Muhammadiyah semestinya telah terdapat unsur suka sama suka yang berlaku antara pihak bank dengan pengguna. Sebab ketika transaksi pembelian uang elektronik berlangsung, pengguna dianggap telah menyetujui setiap prosedurnya. Dalam hal ini telah sesuai dengan firman Allah Swt di Surat Annisa ayat 29:

"Hai orang-orang yang beriman, janganlah kamu saling memakan harta sesamamu dengan jalan yang batil, kecuali dengan jalan perniagaan yang berlaku dengan suka sama-suka di antara kamu" (QS. An-nisa : 29)

\footnotetext{
${ }^{20}$ Fatwa DSN Nomor 116/DSN-MUI/IX/2017 Tentang Uang Elektronik Syariah
} 
Pendapat Para Ulama di Kabupaten Gresik Terhadap ...

Bagaimanapun jenis transaksi itu selagi tidak merugikan salah satu pihak dan tidak mengandung unsur riba maka uang elektronik dapat dinyatakan hukumnya boleh. Seperti dalam Al-Qur'an surat Ali Imron ayat 130:

"Hai orang-orang yang beriman, janganlah kamu memakan riba dengan berlipat ganda dan bertakwalah kamu kepada Allah Swt supaya kamu mendapat keberuntungan." (Qs. Ali Imron: 130)

Selanjutnya dikatakan oleh Ulama dari Pondok Pesantren Nurul Qur'an al-Istiqomah, bahwa transaksi menggunakan uang eletronik sangatlah transparan. Sebab kita dapat mengetahui dengan jelas perputaran uang kita dalam kartu tersebut. Kita juga dapat mengetahui nilai uang yang terkadung dalam kartu elektroniknya dengan cara mengecek saldo. Ditambahkan oleh Ulama dari Dewan Masjid Indonesia, pembelian saldo uang elektronik yang terdapat dalam kartu uang elektronik harus sejumlah dengan uang tunai yang dibayarkan. Sebab apabila tidak sama jumlahnya maka dapat mengandung unsur riba. Lain halnya dengan biaya yang dikenakan untuk penambahan saldo atau biasa disebut topup. Biaya yang dikeluarkan dapat dianggap sebagai ujrah atau upah. Sebagaimana sesuai dengan Hadis dalam Fatwa DSN Nomor 116/DSN-MUI/IX/2017 sebagai berikut:

"Emas (hendaklah dibayar) dengan emas, perak dengan perak, gandum dengan gandum, beras dengan beras, kurma dengan kurma, dan garam dengan garam, sama dan sejenis haruslah dari tangan ke tangan (sah). Maka, apabila berbeda jenisnya juallah sekehendak kalian dengan syarat kontan."

Dikatakan juga bahwa "Tujuan utama dari harga yang adil dan berbagai permasalahan lain yang terkait adalah untuk menegakkan keadilan dalam transaksi pertukaran dan berbagai hubungan lainnya diantara anggota masyarakat". ${ }^{21}$

21 M. Hasan Ubaidillah, "Membedah Kearifan Sistem Ekonomi Islam (Konstruksi Sistem Ekonomi yang Adil dan Beradab), Maliyah: Jurnal Hukum Bisnis Islam, Vol. 02, No. 02, Desember 2012, 497 
Berdasarkan Fatwa Dewan Syariah Nasional (DSN) Nomor: 116/DSN-MUI/IX/2017 Tentang Uang Elektronik Syariah terdapat ketentuan-ketentuan khusus yang harus dimiliki atau diterapkan pada uang elektronik. Apabila tidak mematuhi aturan yang ada pada Fatwa DSN-MUI, maka uang elektronik tersebut dapat dikatakan melanggar peraturan perundangundangan yang ada pada Fatwa. Pengertian uang elektronik syariah berdasarkan yang ada dalam peraturan Fatwa DSNMUI Nomor 116/DSN-MUI/IX/2017 beserta analisanya yaitu:

1. Diterbitkan atas dasar jumlah nominal uang yang disetor terlebih dahulu kepada penerbit. Dalam pelaksanaannya sebelum diterbitkan oleh pihak penerbit, calon pengguna uang elektronik atau nasabah dari penerbit tertentu menyetorkan nilai uang terlebih dahulu dalam jumlah tertentu sesuai kehendak calon pengguna dengan jumlah yang sama dengan nominal yang ingin dimiliki dalam kartu uang elektroniknya sekaligus menambah biaya pengganti harga kartu sebagai syarat pembelian kartu uang elektronik.

2. Jumlah nominal uang disimpan secara elektronik dalam suatu media yang teregistrasi. Dalam hal ini, nilai dari uang elektronik terismpan dalam bentuk kartu yang telah diregistrasikan terlebih dahulu oleh penerbit.

3. Jumlah nominal uang elektronik yang dikelola oleh penerbit bukan merupakan simpanan sebagaimana dimaksud dalam undang-undang yang mengatur mengenai perbankan. Dimaksudkan bukan sebagai simpanan ialah, jumlah uang elektronik yang tersimpan dalam sebuah kartu tidak dapat dikatakan sebagai simpanan atau tabungan dari pengguna atau pemilik kartu uang elektronik tersebut. Melainkan hanya penggantian dari nilai uang tunai menjadi nilai uang digital dalam kartu. Namun dalam pengisian ulang (topup) dapat dilakukan dengan mengurangi nilai yang terdapat dalam tabungan 
Pendapat Para Ulama di Kabupaten Gresik Terhadap ...

pemilik atau pengguna sesuai dengan bank penerbit kartu uang elektronik.

4. Digunakan sebagai alat pembayaran kepada pedagang yang bukan merupakan penerbit uang elektronik tersebut. Kartu uang elektronik ini hanya dapat digunakan untuk membayar jasa yang dimaksud namun bukan kepada penerbitnya, melainkan kepada merchant yang menyediakan pembayaran menggunakan kartu uang elektronik.

Sehingga dalam hal ini para ulama di Kabupaten Gresik sepakat menyatakan kebolehan dari penggunaan kartu uang elektronik dalam transaksi sesuai Fatwa DSN Nomor 116/DSNMUI/IX/2017 tentang Uang Elektronik Syariah, namun memiliki perbedaan pendapat mengenai kelebihan dan kelemahan uang elektronik sebagaimana akan dipaparkan sebagai berikut:

1. Analisis Pendapat Ulama Nahdlatul Ulama (NU) Kabupaten Gresik

Pengertian dari uang elektronik tidak dapat dipersamakan sebagai uang atau sebagai pengganti uang itu sendiri tetapi alat yang memudahkan transaksi disaat melakukan jasa yang dimaksud. Sebab definisi uang elektronik bertentangan dengan definisi uang yang sesungguhnya. Karena uang elektronik yang selama ini digunakan tidak memiliki nilai tukar. Hanya sebagai alat ganti pembayaran, yang ketika digunakan untuk pembayaran suatu transaksi hanya mengurangi nilai yang terkandung dalam sebuah kartu, bukan nilai dari uang itu sendiri. Hukum uang elektronik dinyatakan boleh, sebab kembali merujuk pada kaidah dasar muamalah, bahwa segala transaksi hukumnya boleh, asal tidak ada dalil yang melarangnya. bahwa transaksi menggunakan uang elektronik ini dianggap sah karena kita dapat mengetahui saldonya secara transparan. 
Kelebihan dari uang elektronik diantaranya adalah memudahkan transaksi khususnya dalam efisiensi waktu, serta meningkatkan tingkat kesadaran akan kemajuan teknologi di kalangan masyarakat. Sebaliknya, uang elektronik juga memiliki kekurangan. Salah satunya adalah pengurangan tenaga kerja yang diakibatkan penggantian tenaga kerja oleh mesin kartu uang elektronik. Tentu saja hal ini berpengaruh pada tingkat pengangguran yang bertambah di setiap daerah, khususnya daerah Kabupaten Gresik.

2. Analisis Pendapat Ulama Muhammadiyah Kabupaten Gresik

Inovasi berupa uang elektronik ini adalah permasalahan baru dalam bidang ekonomi. Sedangkan masalah ekonomi adalah lingkup muamalah bukan lingkup ubudiyah. Maka dalam masalah uang elektronik ini juga termasuk dalam lingkup muamalah. Segala jenis transaksi hukumnya boleh dilakukan, kecuali ada dalil yang mengharamkannya. Sepanjang transaksi yang dilakukan juga tidak digunakan untuk hal yang dilarang agama dan mengandung unsur gharar maka hukumnya boleh.

Kelebihan menggunakan uang elektronik di masa kini menjadikan setiap transaksi jadi lebih mudah, akan tetapi hal itu pula yang dapat menyebabkan masyarakat cenderung semakin malas. Semakin dipermudah dengan teknologi maka interaksi dalam transaksi juga semakin berkurang disebabkan transaksi yang menggunakan mesin. Sehingga hal ini menyebabkan manusia cenderung bersifat individual sebab tidak perlu melakukan interaksi atau percakapan saat transaksi.

3. Analisis Pendapat Ulama Lembaga Dewan Masjid Indonesia Kabupaten Gresik 
Pendapat Para Ulama di Kabupaten Gresik Terhadap ...

Uang elektronik sebagai media pengganti uang tunai. Dimana uang tunai yang selama ini kadang menyulitkan dalam membawanya kini dipermudah dengan hadirnya uang elektronik. Hal ini dianggap sebagai satu bentuk pembaruan dari kartu ATM dan kartu debit yang biasanya hanya digunakan oleh orang- orang tertentu sedangkan uang elektronik dapat digunakan oleh berbagai kalangan karena proses dalam memperoleh kartu uang elektronik tidak perlu menjadi nasabah salah satu bank.

Pembelian saldo uang elektronik yang terdapat dalam kartu uang elektronik harus sejumlah dengan uang tunai yang dibayarkan. Sebab apabila tidak sama jumlahnya maka dapat mengandung unsur riba. Lain halnya dengan biaya yang dikenakan untuk penambahan saldo atau biasa disebut topup. Biaya yang dikeluarkan dapat dianggap sebagai ujrah atau upah.

Kelebihan hadirnya uang elektronik selain mempersingkat waktu proses transaksi, yaitu mengurangi pembulatan nilai uang yang kadang merugikan salah satu pihak dan juga menjadi pemicu berkurangnya biaya percetakan uang tunai yang kini digantikan dengan uang bentuk digital dalam uang elektronik. Namun sebaliknya, uang elektronik juga memiliki kekurangan, yaitu sosialisasi tentang uang elektronik yang dalam kenyataannya belum spenuhnya merata.

4. Analisis Pendapat Ulama Yayasan Pondok Pesantren Qomaruddin (Bungah, Gresik)

Uang elektronik hanyalah sebuah kartu yang berisikan nilai uang sejumlah yang kita kehendaki. Statusnya dalam setiap transaksi hanya alat bantu pembayaran di tempat- tempat tertentu yang memang menyediakan fasilitas pembayaran menggunakan kartu uang elektronik. Dalam masalah duniawi Rasulullah menyerahkan pada umatnya. Urusan 
ekonomi termasuk dalam masalah dunia maka selagi uang elektronik belum ditemukan hal- hal yang membuatnya haram maka hukumnya boleh.

Dalam mekanismenya, salah satu kelemahan uang elektronik terletak pada nilai uang yang tersimpan di kartu uang elektronik apabila kartunya hilang maka nilai uang yang didalam kartu tersebut ikut hilang dan sebagai pemilik tidak dapat meminta pertanggung jawaban pada pihak manapun. Sebaliknya, kelebihan dari uang elektronik ini misalnya mengurangi peredaran uang palsu. karena uang kertas yang banyak dipalsukan kini berganti menjadi uang yang berada dalam kartu dan berbentuk digital.

5. Analisis Pendapat Ulama Pondok Pesantren Nurul Qur'an Al-Istiqomah (Sukorejo, Gresik)

Status uang elektronik dalam transaksi ini adalah sebagai alat pembayaran bukan sebagai mata uang. Karena sesungguhnya mata uang kita tetaplah rupiah yang berbentuk uang kertas dan uang logam. Dalam pembelian saldo uang elektronik pun perlu menggunakan uang tunai yang berbentuk kertas dan logam. Maka sudah jelas bahwa uang elektronik hanyalah alat bantu pembayaran manusia di jaman modern.

Kelebihan dalam menggunakan uang elektronik pada setiap transaksi yang paling jelas adalah efisiensi waktu. Namun kekurangannya adalah masyarakat akan cenderung lebih boros, sebab kebiasaan memegang uang tunai mulai terganti dengan menggunakan uang elektronik yang mengakibatkan tidak terkontrolnya pengeluaran. Jika awalnya kita dapat dengah mudah mengetahui berapa sisa uang tunai yang terlihat, lain halnya dengan uang elektronik yang tidak setiap waktu dapat kita pantau pengeluarannya. 


\section{Penutup}

Dari pembahasan yang telah dipaparkan sebelumnya, dapat diambil suatu kesimpulan bahwa para ulama di Kabupaten Gresik menyatakan penggunaan kartu uang elektronik dalam transaksi sebenarnya merupakan kegiatan muamalah yang biasa kita lakukan sehari-hari seperti halnya jual beli, serta penggunaan uang elektronik hanya sebagai media pembayaran atau transaksi. Oleh karena itu para ulama di Kabupaten Gresik sepakat bahwa penggunaan uang elektronik adalah boleh selama tidak mengandung unsur-unsur yang dilarang dalam jual beli. Hal ini berdasarkan prinsip dasar dalam muamalah yang menyatakan bahwa "pada dasarnya muamalah hukumnya boleh selasam tidak ada dalil yang melarangnya". Hal ini juga sesuai dengan Fatwa DSN Nomor 116/DSN-MUI/IX/2017 tentang Uang Elektronik Syariah yaitu diterbitkan atas dasar jumlah nominal uang yang disetor serta jumlah nominal uang disimpan secara elektronik dalam suatu media yang teregistrasi.

\section{Daftar Pustaka}

Abidin, M. Sofyan, "Dampak Kebijakan E-money di Indonesia Sebagai Alat Sistem Pembayaran Baru", Jurnal Ilmu Akuntansi: Universitas Negeri Surabaya, 2016.

Adiyanti, Arsita Ika, "Pengaruh Pendapatan, Manfaat, Kemudahan Penggunaan, Daya Tarik Promosi, dan Kepercayaan terhadap Minat menggunakan layanan Emoney", Jurnal Ilmu Ekonomi: Univeristas Brawijaya, 2015.

Arip, Purkon, Bisnis Online Syariah, Jakarta : Gramedia Pustaka Utama, 2014.

Bahri, Asep Saiful, “Konsep Uang Elektronik Dan Peluang Implementasinya Pada Perbankan Syariah (Studi Kritis Terhadap Peraturan Bank Indonesia Nomor 11/12/PBI/2009 tentang Uang Elektronik)", Skripsi:UIN Syarif Hidayatullah, 2010.

Djazuli, A., Kaidah-Kaidah Fikih, cet. V, Jakarta: Kencana, 2014. 
Fatwa Dewan Syariah Nasional Majelis Ulama Indonesia No: 116/DSN-MUI/IX/2017 Tentang Uang Elektronik Syariah Gemala, Dewi, dkk, Hukum Perikatan Islam di Indonesia, Jakarta: Kencana, 2013.

Herdiansyah, Haris, Metode Penelitian Kualitatif, Jakarta Selatan: Salemba Humanika, 2010.

Hidayati, Siti, et. all., Kajian Operasional E-money, Jakarta: Bank Indonesia, 2006.

Huda, Nurul, et,al, Lembaga Keuangan Islam, Jakarta: Kencana Prenada Media Grup, 2010.

Ismail, MBA, Perbankan Syariah, Jakarta: Prenadamedia Group, 2014.

Karim, Adiwarman, Riba Gharar dan Kaidah-Kaidah Ekonomi Syariah Analisis Fikih \& Ekonomi, Jakarta: Raja Grafindo Persada, 2015.

Komaruddin, Uang di Negara Sedang Berkembang, Jakarta: Bumi Aksara, 1991.

Mardani, Fiqh Ekonomi Syariah, Jakarta: Kencana Prenada Media Grup, 2011.

Masruhan, Metodologi Penelitian Hukum, Surabaya: Hilal Pustaka, 2013.

Musafa'ah, Suqiyah, Hadith Hukum Ekonomi Islam, Surabaya : UIN SA Press, 2014.

Nasution ME dkk, Pengenalan Eksklusif Ekonomi Islam, Jakarta: Kencana Prenada Media Grup, 2007.

Peraturan Bank Indonesia Nomor 20/06/2018/PBI tentang Uang Elektronik

R. Serfianto, dkk, Untung Dengan Kartu Kredit, Kartu ATMDebit, \& Uang Elektronik, Jakarta: Visi Media, 2012.

Rusdiyanto, Aris, "Tinjauan Prinsip Syariah Terhadap Produk E-Money Bank Syariah Mandiri" Skripsi: UIN Syarif Hidayatullah, 2017.

Sakti, Nufransa Wira, Buku Pintar E-commerce, Jakarta: Transmedia Pustaka, 2014.

Sjahdeini, Sutan Remy, Perbankan Islam dan Kedudukannya dalam Tata Hukum Perbankan Indonesia, Jakarta: Pustaka Utama Grafiti, 1999. 
Pendapat Para Ulama di Kabupaten Gresik Terhadap ...

Solikin dan Suseno, Uang: Pengertian, Penciptaan, Dan Peranannya Dalam Perekonomian, Jakarta: Pusat Pendidikan dan Studi Kebanksentralan Bank Indonesia, 2002.

Sugiyono, Metode Penelitian Kuantitatif Kualitatif dan R\&D, Bandung: Penerbit Alfabeta, 2010.

Subhki, Ahmad, Terjemah Kitab Bulughul Maram Min Adilatil Ahkam, Juz 2, Pekalongan: Raja Murah.

Tazkiyyaturrohmah, Rifqy , "Transaksi Uang Elektronik Ditinjau Dari Hukum Bisnis Syariah", Tesis: UIN Sunan Kalijaga, 2016.

Ubaidillah, M. Hasan, "Membedah Kearifan Sistem Ekonomi Islam (Konstruksi Sistem Ekonomi yang Adil dan Beradab), Maliyah: Jurnal Hukum Bisnis Islam, Vol. 02, No. 02, Desember 2012.

Zabidi (Az), Imam, Mukhtasar Shahih Al-Bukhari, Jakarta: Ummul Qura, 2017.

Zuhaili (Az), Wahbah, Fiqh Islam Wa Adillatuhu, terj Abdul Hyyie al-Kattani, et,al, juz 5, Jakarta: Gema Insani, 2011.

www.bi.go.id/id/peraturan/sistempembayaran/pages/pbi_111209.aspx diakses tanggal 30 Oktober 2017

www://bappeda.jatimprov.go.id/bappeda/wpcontent/uploads/potensi-kab-kota-2013/kab-gresik2013.pdf diakses tanggal 20 Juli 2018

Masykuri, Wawancara, 24 Juni 2018

Munir, Wawancara, 26 Juni 2018

Syifaul Qulub, Wawancara, 25 Juni 2018

Taufiqullah, Wawancara, 18 Juli 2018

Zaeni, Wawancara, 27 Juni 2018 